\title{
A Preliminary Study on Historical Development and Evolution of the Longevity Hill in Yuanmingyuan
}

\author{
Qin $\mathrm{Ke}^{1}$, Song Shaoda ${ }^{1}$ and Zhang Zhiguo ${ }^{2}$ \\ ${ }^{1}$ North China University of Technology, Beijing 100144, China \\ ${ }^{2}$ The Administrative Office of Yuanmingyuan, Beijing 100084, China \\ *Corresponding email:zhongljn@126.com
}

Keywords: Yuanmingyuan; the Longevity Hill; historical development; rockery.

\begin{abstract}
The audience hall is the most important place in royal gardens in Qing dynasty, where emperors rehearsed rites and ceremonies. The longevity hill, where is behind of the audience hall, is the boundary of court room space. The Longevity Hill has an important position and a unique style. With sorting out and analyzing drawing and document from Yang-Shi-Fang, graphics and text, results show that the Longevity Hill changed along with changes of the audience hall in nearly 150 years. The existing hill could reflect the style of Daoguang to Xianfeng period. The preliminary study is helpful and valuable for value excavation and heritage preservation of the Longevity Hill.
\end{abstract}

\section{Introduction}

There are two significant scenic spots in Yuanmingyuan--the Longevity Hill and the Happy Sea. The Happy Sea is known as the largest lake in Yuanmingyuan. The Longevity Hill is located behind the Main Audience Hall, which is the closing part of this scenic spot. The Forty Scenes of Yuanmingyuan the Main Audience Hall: "The Main Audience Hall is located inside the Second Gate, which is not carved or painted, reflecting the meaning of nature. Behind the house the rocks are steep and stalagmites are craggy. "The Main Audience Hall is a ritual place for holding court meetings, festivals, banquets for client King, and dinners for the courtiers. Its function is similar to the Hall of Supreme Harmony and the Hall of Preserving Harmony of the Forbidden City, which has a very high political status in the Qing Dynasty. The Longevity Hill is a boundary hill dividing the court place and bedroom place. The south side of the Longevity Hill is the end point of the space of imperial ritual, while its northern side is the starting point of the space of bedrooms. In the imperial gardens of the Qing Dynasty, it seems to be a fixed form to use the mountain style to divide the space of court and bedrooms. But due to the special position of the Main Audience Hall, the status of the Longevity Hill is very unique. For example, the steep rocks resembling thousands of ritual tablets pointing sky on the Longevity Hill cannot find in other gardens. At present, the scholars' researches mostly refer to the special form of the Longevity Hill. Guo Daiheng's team discussed the change and restoration of the Longevity Hill. Jia Jun made an overall comparison for the court and bedroom space of the imperial gardens of the Qing Dynasty. At present, there has not been a more comprehensive and special discussion on the Longevity Hill. Based on the collection and arrangement of the drawing documents, images, texts and surveying and mapping materials related to the Longevity Hill and the investigation of the existing rockeries, this paper discussed the history and evolution of the Longevity Hill in order to attract other excellent papers.

\section{Function and Connotation of the Longevity Hill}

\subsection{Function.}

The Longevity Hill, which is located behind of the Main Audience Hall, is the terminus of the axis which starts from Fan Lakes to the Great Palace Gate, the Second Gate and the Main Audience Hall. 
At the south slope of the Longevity Hill, the rocks are steep and stalagmites are craggy, which enhanced the effect of this area as the end point of imperial ritual space. The Longevity Hill is the starting point of the bedroom space as well. The Emperor's Private Apartments or called Jiu Zhou Qing Yan is the emperor's bedroom place in Yuanmingyuan, which starts from the north side of the Longevity Hill. Viewed from this site, the Longevity Hill is also a barrier to the landscape of lakes and hills. Furthermore, the Longevity Hill is a node of spatial switching, for the conversion from the imperial ritual space to the bedroom space is embodied through the winding path on the Longevity Hill. This winding path is not only a passage, but also metaphors the transformation from imperial court to seclusion, monarch to individual, seriousness to leisure. The spatial switching of the Longevity Hill is also reflected in sight on east-west direction. To the east, it's the palaces and courtyards, including Qin Zheng Guan Xian and Bao He Tai He. While to the west, there are paths connected to the Long Spring Lodge of the Immortal. The Forty Scenes of Yuanmingyuan• the Long Spring Lodge of the Immortal: "Going west along the entrance of the Longevity Hill Pass, houses were in deep space, corridor was meandering[ (Qing)Tang Dai, Shen Yuan. The Forty Scenes of Yuanmingyuan. (Beijing: China Architecture \& Building Press, 2008).”

\subsection{Political and Cultural Connotation}

In politics, the Longevity Hill is a metaphor of the immortal sovereignty. There is nothing can be more magnificent and as eternal than mountain and sea in the world. The most significant body of water and the most important hill site in Yuanmingyuan are the Happy Sea and the Longevity Hill. The generally extended form of the Longevity Hill represents its eternity of stability, and the forest of peaks symbolizes its incredible height which is even capable of blocking clouds and stars. As the end zone of the space of imperial ritual, the craggy stalagmites are metaphorized as all domestic officials and representatives of other countries worship the emperor. The natural view of thousands of ritual tablets pointing sky is formed by vertical joint development and differentiation of granite, the result of which gives rise to the very sharpened rocks and even outline that looks just like a ritual tablet. That's how it gains its name. The most famous views like thousands of ritual tablets pointing sky are Suzhou Tianping Mountain and Jiangxi Sanqing Mountain.

The cultural connotation of the Longevity Hill includes both unification and differentiation of ritual and music. The order of all things in the world is showed in the imperial etiquette. The harmony of nature can be seen through gardens. The connotation of ritual and music carried over to mountain symbolizes mercy and longevity, while mercy and longevity are the bailment of happiness and longevity of an emperor. What a man deeply wants but cannot get is no more than happiness and longevity. Therefore, the name of the Longevity Hill and the Happy Sea was to bless the emperor happy and long life.

\section{Development and Evolution of the Longevity Hill in History}

According to the present publications in connection with the condition of the Longevity Hill, including drawing documents, historical image materials, literature and mapping information, the development and evolution of the Longevity Hill and its rockery could be divided into five stages: formative stage, developmental stage, alternating stage, failure stage and protection stage.

\subsection{Formation stage - from the reign of Yongzheng to the initial reign of Qianlong}

After Yongzheng ascended the throne, Large-scale construction activities was started in Yuanmingyuan. The Main Audience Hall and surrounding scenic spots were built during the first to third year of Yongzheng's reign. The Longevity Hill was also formed during this period, which became the boundary hill of court space and bedroom space.

At the fourth year of Qianlong's reign, two court artists, Tang Dai and Shen Yuan, painted for the emperor the Forty Scenes of Yuanmingyuan, which said: "The Main Audience Hall is located inside the Second Gate, which is not carved or painted, reflecting the meaning of nature. Behind the house the rocks are steep and stalagmites are craggy." In the Figure (left of Figure 1), the south entrance of 
the Longevity Hill path is partly showing. On the left side, there is a tree, two shrubs, and a few small vertical rockery peaks. On the right side, there are shrubs and vertical rockery peak. In front of the main peak of the Longevity Hill, there are six Chinese pine trees. On the main peak, there are more than twenty steep rocks, and horizontal rocks peek out from the west side of them. The back of the Longevity Hill, where trees are blooming, is facing the lake. At that time, the soil slope on the west side of the Longevity Hill Pass didn't extend to the translation room which is located beside the west side-hall, and the branch of the Donghu Hill was located near the eunuch room beside the west side-hall.

Imperial Poems on the Forty Scenes of Yuanmingyuan (middle of Figure 1), which was painted no later than the 11th year of Qianlong's reign by Zhang Ruo'ai, is a copy of the Forty Scenes of Yuanmingyuan. During the reign of Guangxu, there were reprint of this copy. According to Wang Shihua's textual research, the copy Zhang Ruo'ai painted is a reproduction of Tang Dai's silk scroll painting. The content in this copy is similar to it in the silk scroll, but the buildings Zhang painted are bigger. The S-shaped winding path on the Longevity Hill is clearly visible in the Figure. The amount of steep rocks on the main peak in Zhang's drawing is less than what in Tang's painting, and there is a deal of horizontal rocks lying around the roots of these steep rocks. The reprint is similar to the copy. Neither of the two pictures shows the cross passage in the courtyard of the Main Audience Hall.

The Main Audience Hall was also drawn on Peng Hu Chun Yong (right of Figure 1), which is collected by the Palace Museum. According to Zhang Enyin's textual research, Peng Hu Chun Yong was drawn according to Sun Hu and Shen Yuan's line drawing, which was drawn in the early year of Qianlong's reign. In this Figure, the Longevity Hill path is clearly showing, and the amount of steep rocks is little. Horizontal rocks lying around the roots of these steep rocks are conspicuous and clear.

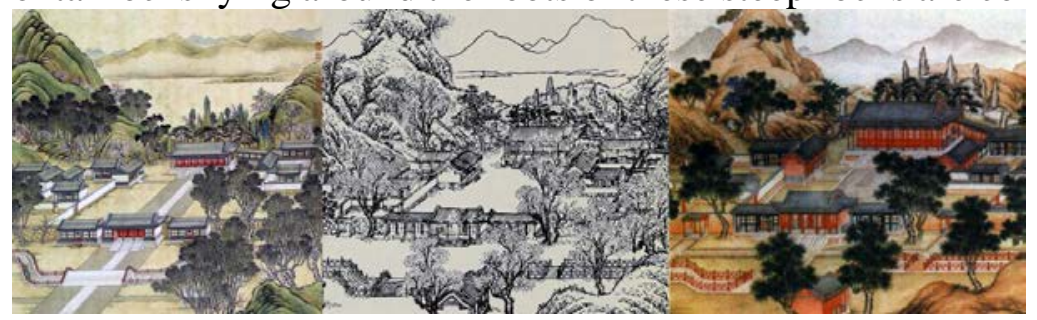

Figure 1 Figure of the Longevity Hill in Chinese drawing(left and right from Guo Daiheng, Drawing and Documents of Yang-shi-fang: Memory Heritage of Yuanmingyuan, middle from Malone C.B..

History of the Peking Summer Palaces under the Ch'ing Dynasty.)

\subsection{Developmental stage - the mid-late reign of Qianlong}

According to the current public drawing documents and the research of scholars, the earliest general drawing of yuanmingyuan was only finished off in Qianlong's reign. The drawing time of the parts relating to the Longevity Hill of these drawing documents covers the mid-late reign of Qianlong to the late reign of Xianfeng, about 100 years. During this period, several changes had taken place in the Longevity Hill area. In the early Qianlong’s reign, the Main Audience Hall was still "not carved or painted", for there wasn't bracket system beneath the cornice, and it was gray tiles on the roof. During the late reign of Qianlong, Duocai bracket system had been used in the Main Audience Hall. Compared to the formative stage, the Main Audience Hall didn't manifest the meaning of nature, but it was more magnificent.

It is confirmed that sample 1704 (left of Figure 2) and sample 043-1 (right of Figure 2) are parts of the general drawing finished in mid-late reign of Qianlong. The section about the Longevity Hill in sample 1704 altered at least three times, which is very important to study the evolution of the Longevity Hill. And there is a complete square grid in sample 043-1, which provides a very convenient condition for studying the landscape pattern and plane control of Yuanmingyuan.

Sample 1704 and sample 043-1 show that:

(1) The width of the Longevity Hill was small. The hill was divided into east part and west part by the pass. The branch of the west side of the Longevity Hill extending to north was separated by road. The east side of the Longevity Hill extended to the west side of Fu Chun Lou along the lake, and 
extended northward to the south side of the Ru'yi Bridge.

(2) The Longevity Hill Pass was located in the northwest of the Main Audience Hall. The pass was connected and concerted with the channel which was composed of the east side of the west side-hall and the west gable wall of the Main Audience Hall. The width of the Longevity Hill Pass was large. The south entrance of the pass occupied about $4 / 5$ of a square in square grid, and the north entrance of the pass occupied about $2 / 5$ of a square.

(3) The Longevity Hill was mainly consisted of soil slope, while rocks were mainly distributed behind the Main Audience Hall and on both side of the winding path. The vertical rocks, like steep peak, mainly stood behind the Main Audience Hall.

(4) The distance between the Main Audience Hall and the Longevity Hill were relatively large, which occupied approximately $1 / 3$ to $1 / 2$ of a square in square grid.

(5) It was the same as the Forty Scenes of Yuanmingyuan that the branch of the Donghu Hill was located near the eunuch room which is beside the west of the west side-hall.

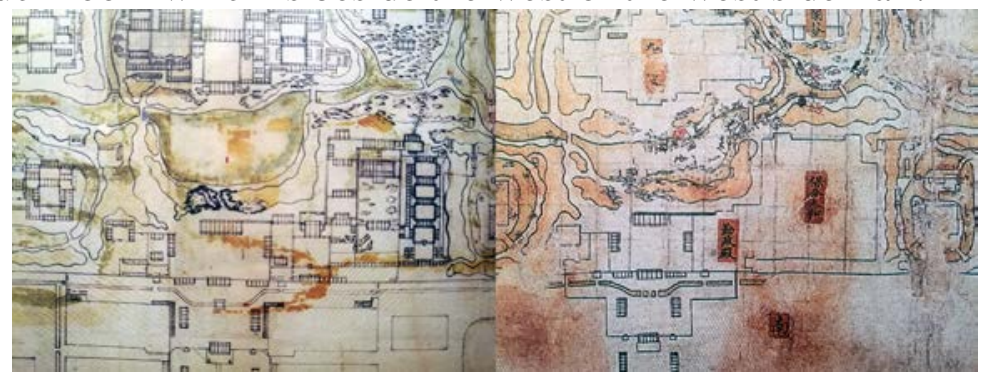

Figure 2 Drawing from Yang-Shi-Fang in mid-late reign of Qianlong(from Guo Daiheng, Drawing and Documents of Yang-shi-fang: Memory Heritage of Yuanmingyuan)

Qin Ding Ri Xia Jiu Wen Kao • Charter One of Yuanmingyaun was written in the late reign of Qianlong, which said: "The Main Audience Hall, in which there are seven openings, is located inside the Second Gate. There are five openings in its both side-halls. The Longevity Hill Hall is behind it.” Actually, it is the Longevity Hill, where steep rocks and craggy stalagmites stood, rather than other hall that close to the back of the Main Audience Hall. Zhang Enyin regarded this article as a mistake. But Chen Huan Shi Lue followed this article.

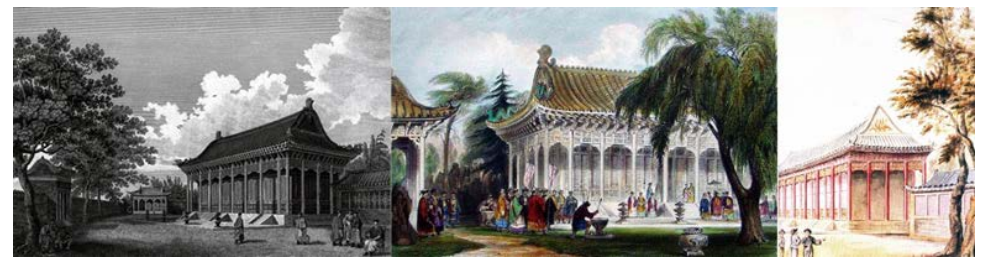

Figure 3 Figure of the Longevity Hill in Chinese drawing(from Guo Daiheng, Drawing and Documents of Yang-shi-fang: Memory Heritage of Yuanmingyuan)

At the fourth year of Qianlong's reign, the date 1793, Lord Macartney visited China. George Leonard Staunton wrote a book called an Authentic Account of an Embassy from the King of Great Britain to the Emperor of China after this visit. There are two drawing Figures (left and middle of Figure 3) in this book, in which the perspective is clear and accurate, which provides valuable materials for the study of the Longevity Hill and the Main Audience Hall in the late reign of Qianlong. One of the two Figures is to look the Main Audience Hall from the east side-hall. In this picture, the rockery peaks (steep rocks) on hill behind the Main Audience Hall are clearly showing. The height of these rockery peaks isn't above the height of the hall. And there is a pine tree in front of the rockery peaks. A watercolor (right of Figure 3) which was originally contained in VISITEURS DE L'EMPIRE CELESTE is similar to this picture. Another Figure is to look the Main Audience Hall from the south of west side-hall. In the visual corridor formed by the west side-hall and the Main Audience Hall, the entrance of the Longevity Hill and the nearby smaller rockery peaks are clearly showing. In addition, there is a tree in the west side of the Longevity Hill Pass, and there is a pine tree in the opposite. These contents dovetail beautifully with the description of court paintings like the 
Forty Scenes of Yuanmingyuan. All these drawings show that there is a platform in front of the Main Audience Hall, which is one step up from the ground, and there are four censers in front of the platform.

At that time, the Longevity Hill Pass is relatively broad and flat. In lunar January, the third year of Jiaqing's reign, He Shen "unexpectedly rode straight into the left door, passed the Main Audience Hall, and finally rode to the Longevity Hill Pass". The incident was the second of the twenty crimes He Shen committed declared by the emperor Jiaqing.

\subsection{Alternating stage - the reign of Jiaqing to the tenth year of the reign of Xianfeng}

During the reign of Jiaqing, Daoguang and Xianfeng, the construction activity in Yuanmingyuan is relatively frequent, and four changes had also taken place in the Longevity Hill and its vicinity. The four parts are as follows.

The first change of the Longevity Hill taken place after emperor Jiaqing come into power. During this period, there was a lot of partial modifications of Yuanmingyuan. Sample 1370 (left of Figure 4) and sample 043-3 (right of Figure 4) are the drawing documents of the late reign of Jiaqing which refer to the Longevity Hill. Compared with the condition of the Longevity Hill in the mid-late reign of Qianlong, the variation in this period is mainly reflected in:

(1) The revetment of the Front Lake had changed. The revetment at the north entrance of the Longevity Hill Pass and the revetment at the south central axis of the Emperor's Private Apartments extended to the lake. It seems to be used for docking ships.

(2)The hill at the south side of the Ru'yi Bridge, which is the branch of the Longevity Hill, had changed a little. In mid-late Qianlong's reign, the distance from it to the hill which is located in the north side of Tai He Bao He was closer. In sample 043-3, the edge of the hill was semicircle, which is consistent with the description in sample 043-1.

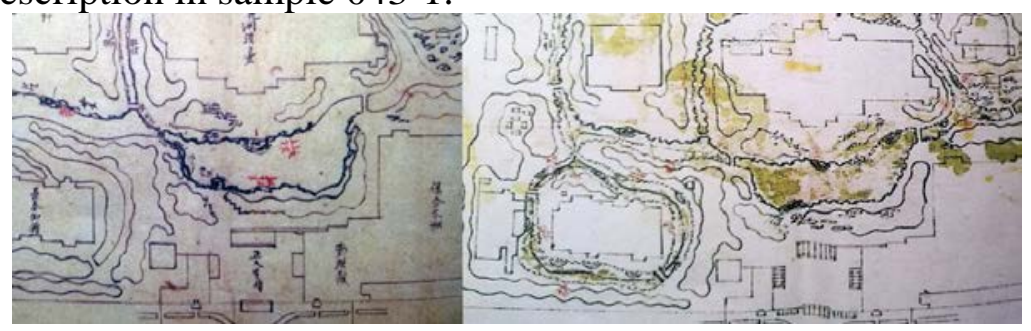

Figure 4 Drawing from Yang-Shi-Fang in late reign of Jiaqing to early reign of Daoguang(from Guo

Daiheng, Drawing and Documents of Yang-shi-fang: Memory Heritage of Yuanmingyuan)

The second change took place in the mid-late Daoguang's reign. Relevant drawing documents include sample 1306, sample 043-2 (upper left of Figure 5), sample 001-2 (bottom of Figure 5) and book 4140 (upper right of Figure 5). Compared with the condition of the Longevity Hill in the late reign of Jiaqing, the variation in this period is mainly reflected in:

(1) The northwest branch of the Longevity Hill is connected with the Donghu Hill nearby the Long Spring Lodge of the Immortal.

(2) The amount of buildings on the hill which is located in the south side of the Ru'yi Bridge added, and there were more rocks on the slope around the buildings.

(3) The rock steps were added in the south and north side of the corridor which is located in the east side of the Main Audience Hall.

In the ninth year of Daoguang's reign, the date 1829, the government suppressed the Zhang'ge'er Rebellion. For this reason, Daoguang asked court artists draw the painting album of the government suppressing the Zhang'ge'er Rebellion in Daoguang's reign, which is collected in the Palace Museum. The tenth and last painting of the album called banqueting the victorious generals and soldiers in the Main Audience Hall (Figure 6), which was affected by the perspective of Western painting, shows the scene of the Main Audience Hall and its vicinity. In this painting, the rock steps were already existed in the corridor which is located in east side of the Main Audience Hall, and the hill behind the translation room which is located in the north side of the west side-hall resembles what had painted in the Forty Scenes of Yuanmingyuan• the Main Audience Hall. But the steep rocks 
around the Longevity Hill Pass become horizontal rocks.

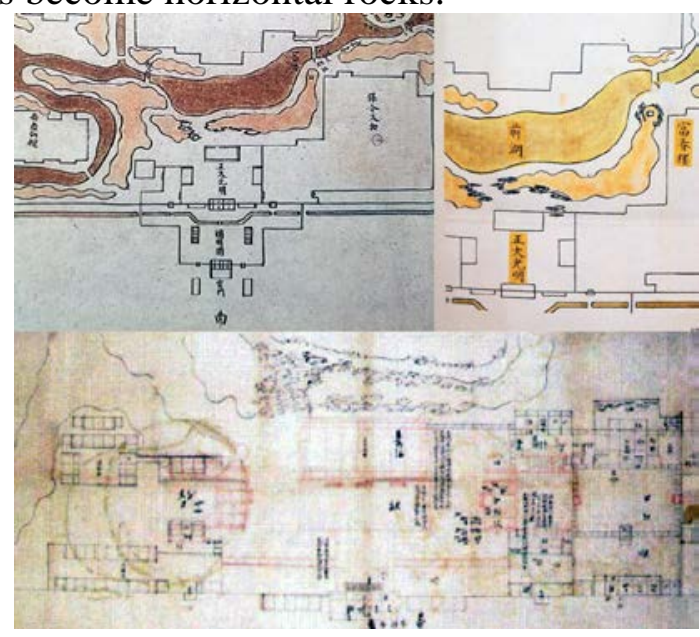

Figure 5 Drawing from Yang-Shi-Fang in late reign of Daoguang to early reign of Xianfeng(from Guo Daiheng, Drawing and Documents of Yang-shi-fang: Memory Heritage of Yuanmingyuan)

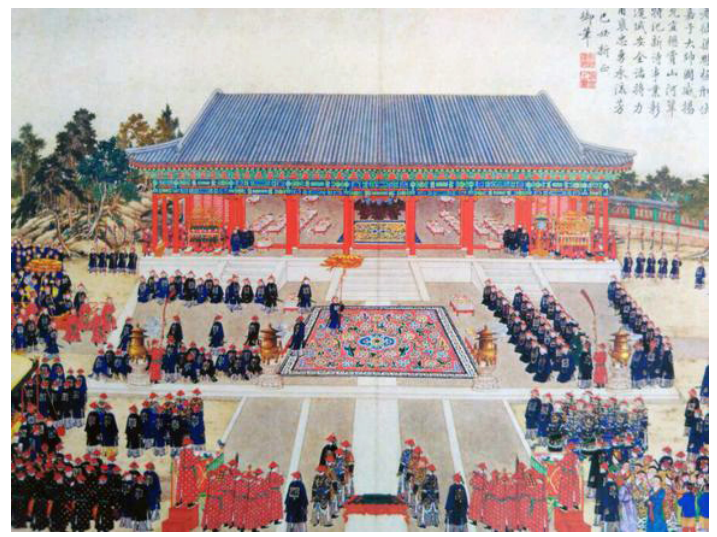

Figure 6 Figure from painting album of the government suppressing the Zhang'ge'er Rebellion in Daoguang's reign(from Guo Daiheng. Gone Brilliant: Research and Protection of Old Summer Palace Landscape and Architecture)

The third change took place from the late reign of Daoguang to the mid-early reign of Xianfeng. Sample 001-2 is the relevant drawing document. Compared with the condition of the Longevity Hill in the mid-late reign of Daoguang, the variation in this period is mainly reflected in:

(1) The main part of the Longevity Hill was thickened. The distance from the Main Audience Hall was significantly shorter than before. And the southwest revetment of the Front Lake seemed to have shifted northward compared with it in previous stages.

(2) The width of the Longevity Hill Pass was shrunk, and the amount of rocks increased obviously.

(3) The hill in the north side of the west side-hall courtyard enlarged and extended to the north side of the west side-hall, which enhanced the path of the Longevity Hill Pass.

The fourth change took place in the late Xianfeng's reign. Relevant drawing documents include sample 1203 (left of Figure 7), a full picture which is collected by the Musée Guimet in France, sample 1704, book 3892 (middle of Figure 7) and book 5462 (right of Figure 7). Compared with the condition of the Longevity Hill in the late reign of Daoguang, the variation in this period is mainly reflected in:

(1) The branch of the northwest side of the Longevity Hill was separated with the Donghu Hill and the branch of the north side of the Longevity Hill was divided by a road.

(2) The Longevity Hill Pass moved eastward and was closed to the central axis of the Main Audience Hall, which seems to be related with the partition board door installed in the middle five openings of the north corridor of the Main Audience Hall.

(3) The soil hill of the west side of the Longevity Hill added a little to the southwest. 


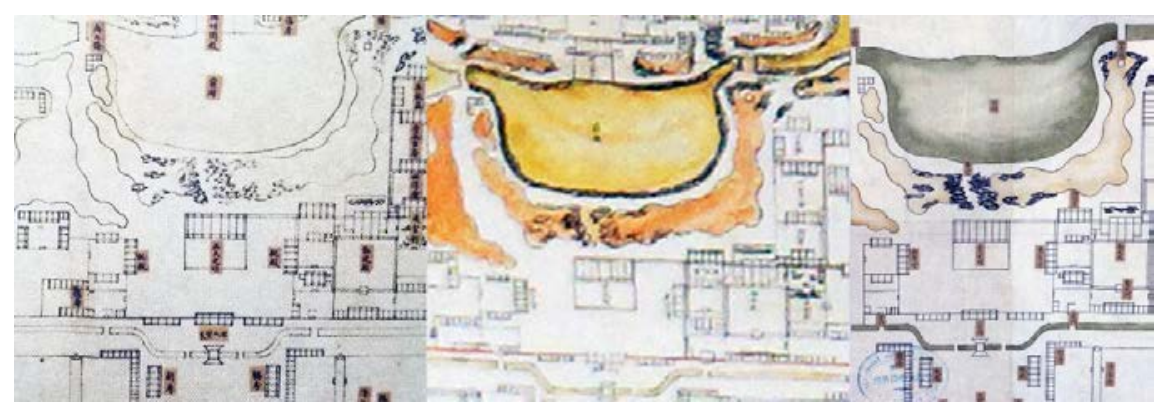

Figure 7 Drawing from Yang-Shi-Fang in late reign of Xianfeng(from Guo Daiheng, Drawing and Documents of Yang-shi-fang: Memory Heritage of Yuanmingyuan)

\subsection{Failure stage — from the tenth year of Xianfeng's reign to 1949}

In the tenth year of Xianfeng's reign, the date 1860, Yuanmingyuan and the Main Audience Hall therein was burnt down by anglo-french allied forces. R.J.L.M'Ghee wrote about the Longevity Hill: "There was a corridor behind the Main Audience Hall, whose both sides could pass. The south side of corridor was close to the back wall of the hall, while the north side almost leaned against a large piece of rockery". In the twelfth year of Tongzhi's reign, the date 1873, the emperor ordered to repair the Yuanmingyuan. But he canceled his order in the next year. In the 21st year of Guangxu's reign, the date 1895, Kang Youwei visited Yuannmingyuan and saw the scene that "it seems that Yaunmingyuan is a desolate place where grasses grown everywhere and buildings was destroyed to rubble, but there are still lots of buildings on the Happy Sea and the Longevity Hill”. After the Eight-Power Allied Forces invaded Beijing in 1900, the 26th year of Guangxu's reign, Yuanmingyuan suffered the destruction and theft from bandits, warlords, bureaucrats, local ruffians and profiteers for a long time.

In 1933, the Works Bureau of Beiping made a surveying and mapping activity about the ruins of yuanmingyuan, and finished the drawing topographic map of the ruins of Yuanmingyuan, in which the Longevity Hill was still existed. In the same year, C.B.Malone published his book History of The Peking Summer Palaces under The Ching Dynasty, in which there is a photograph of the ruins of the Main Audience Hall and a note of this photograph. The note says: "Reeds collected from the shallow lake were sold to make cushions and awnings. The reed reapers' huts occupied a part of the stone platform of the Main Audience Hall, and the rockery behind it was also being destroyed.” This seems to be the earliest photo image of the Longevity Hill, and what is reflected from the image is the scene of the destruction of the Longevity Hill, which makes the image more valuable. The image reflects several details, that:

(1) The main steep rocks on the Longevity Hill had been dismantled at that time.

(2) Compared with the platform, the height of the remains of the Longevity Hill was about 5-6 meters.

(3) The Central Line of the platform is clearly showing. According to the perspective, it is clear that in the late Xianfeng's reign the Longevity Hill Pass was changed to the rocky path.

(4) The image resembles the existing form of the Longevity Hill, especially the rocks in the west side of the central axis of the hill, but the existing rocks are less. According to the fact, it is speculated that the preserved Longevity Hill toppled down, grew old and fell off naturally on the basis of that and there was less man-made interference than ever before.

Regarding the whereabouts of the stalagmites in the Longevity Hill, Zeng Zhaofen and others thought that some of the stalagmites were moved to the Hui Pavilion area, which is located in the east side of the front hill of Yuanmingyaun. 


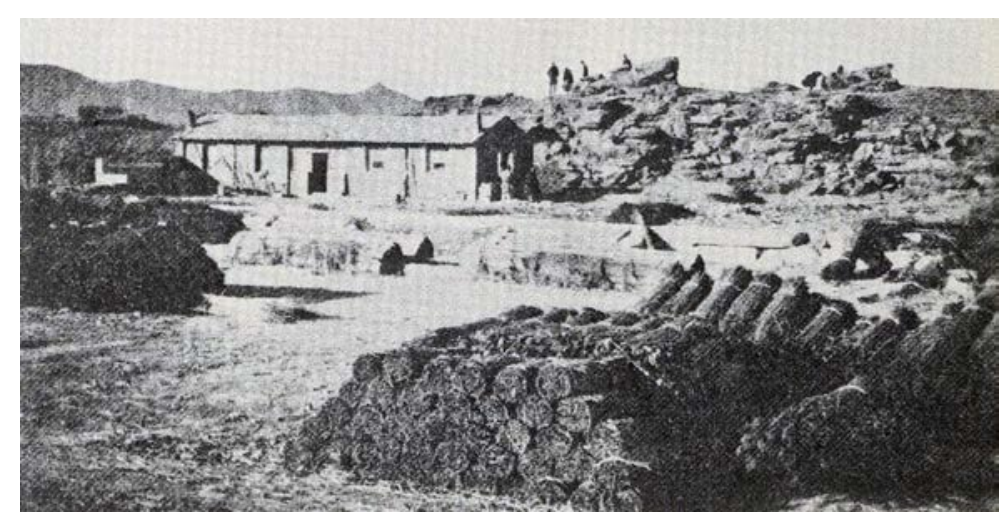

Figure 8 A photograph of the Longevity Hill (from Malone B.C. History of The Peking Summer Palaces under The Ching Dynasty)

\subsection{Protection stage—after 1949}

In the early period of new China, Premier Zhou Enlai made a clear instruction to protect the site of yuanmingyuan. In 1956, trees began to be planted in the site of Yuanmingyuan. In 1959, the site of Yuanmingyuan was designated as a park. In 1960, the site of Yuanmingyuan was designated as one of the Major Historical and Cultural Site Protected at the District Level. In 1976, Yuanmingyuan management office was established. In 1988, Yuanmingyuan Ruins Park was declared as one of the Major Historical and Cultural Site Protected at the National Level, and officially opened to the society. In 1996, Yuanmingyuan Ruins Park was named the patriotic education base by six ministries. In 1998, Yuanmingyuan Ruins Park was named "Beijing national defense education base" by Beijing defense education committee. In 2000, the state administration of cultural heritage officially approved the planning of the site park of yuanmingyuan. In 2008, Yuanmingyuan Ruins Park passed the review of the 4A scenic spot of the national tourism administration. In 2010, Yuanmingyuan Ruins Park was awarded one of the "new 16 sceneries in Beijing".

Guo Daiheng's team (2012) analyzed the survey map of the ruins of the longevity hill and discussed the restoration of the longevity hill during restoring the buildings in the Main Audience Hall. The measured drawing which was drawn in 1965 shows that part of The Longevity Hill was dug, and that the altitude of the top and the foot of the hill was 49.63 meters and 44.5 meters. But the measured drawing which was drawn in 2002 shows that the Longevity Hill only remained the middle of the body, and that the altitude of the top and the foot of the hill was 49.91 meters and 44.5 meters. The archaeological survey results in 2004 show that the distance between the south side of the middle part of the hill and the Main Audience Hall was 2.5 meters, and that the altitude of the top of the hill was 50.799 meters. The width of the east part of the hill,whose altitude was 46.584-46.044 meters, was approximately 6 meters. The distance between the south side of the east part and a climbing corridor was 2.5-4.5 meters. The width of the west part of the hill was 9-22 meters, where there were three small rolling hills from the east to the north, whose altitude was 45.966-47.64 meters. Finally, the length and the width of the rocky path between the middle part and the west part were 24.3 meters and 3.3 meters. Guo's team considered that the Longevity Hill was heaped up around the north side of the Front Lake with plenty of soil and a few rocks. Stalagmites were placed in the middle part of the hill. There was a path led to the southwest corner of the former lake from the opening of the west part of the hill. A rocky path of the Longevity Hill was broken in the middle of the hill during the late Qianlong's reign to the early Daoguang’s reign.

According to the survey of the Longevity Hill, which the author made in 2017, the hill was similar to the aerial mapping image in 2009 (top of Figure 9). There were more remnants in the middle part of the hill, but many rocks fell off, which were scattered in the surrounding area in a natural state (lower left of Figure 9). The area near the central axis of the Main Audience Hall, especially the rocks on the west side of the hill, has a high consistency with Malone's photographic image. Traces of the rocky path could be found near the central axis and rocks on the east side had fallen off seriously. But this part can still be compared and identified with the images taken by Malone. The Longevity Hill Pass 
was clearly showing. Although the rocks on the both sides of the winding path have fallen off seriously, but its boundary was distinct. There was a remained rock steps about $3.5 \mathrm{~m} * 2.5 \mathrm{~m}$ on the north side of the pass. This situation is not consistent with the pattern of the Longevity Hill in the late reign of Xianfeng, which is shown in sample 1203, a full picture which is collected by the Musée Guimet in France, book 3892, and 5462. But it seems to be more close to the pattern in sample 001-2 and sample 001-3. The reason of that needs further discussion and research. The damage of the existing rockery was relatively serious, for the crevices of some rocks could be observed clearly and the phenomenon of weathering of some rocks (lower right of Figure 9) was even found. Compared with the image materials of the last ten years, miscellaneous trees (mainly pseudoacacia) grew rapidly, which brought some adverse effects on the Longevity Hill although the greening effect of it was good.

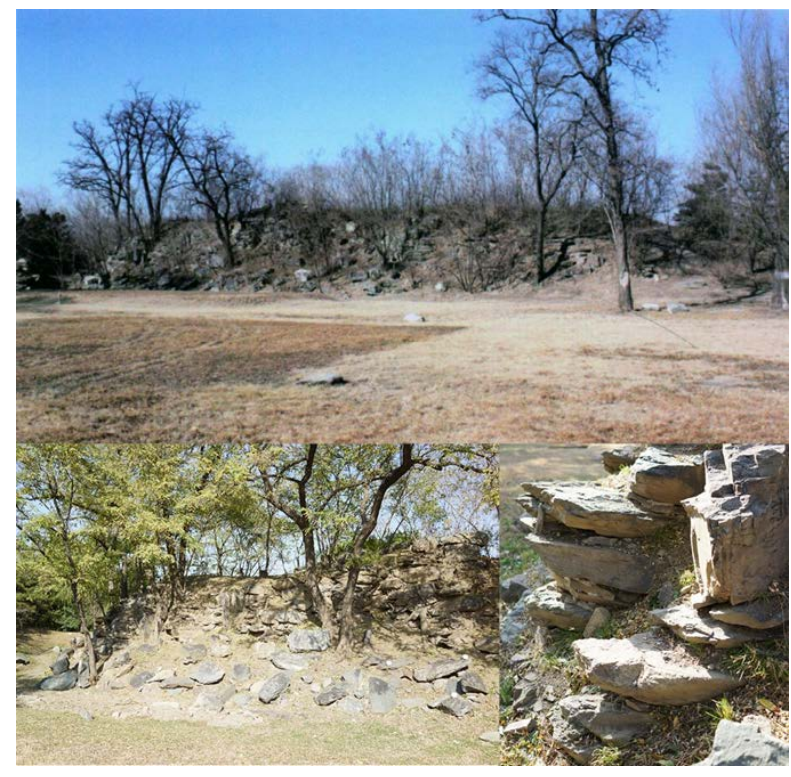

Figure 9 Current situation of the Longevity Hill(top from Guo Daiheng, Drawing and Documents of Yang-shi-fang: Memory Heritage of Yuanmingyuan, button by the author)

\section{Conclusion}

The Main Audience Hall, which was used to hold meetings and imperial ceremonies, is the most important place in the royal garden in Qing dynasty. As the boundary hill dividing the court place and bedroom place, the Longevity Hill, which is behind the Main Audience Hall, has changed a great deal in situation, content, form and so on during the 150 year from the formation to the destruction. Its change and the change and adjustment in the imperial ritual space represented by the Main Audience Hall were basically synchronized. Although there were only some remained rocks on the Longevity Hill, they could also reflect the style and feature of the reign of Daoguang and Xianfeng. The shape of the existing rockery was similar to it in 1933. The discussion on historical development and evolution of the Longevity Hill has some significance for the comprehensive and in-depth exploration of the value of the Longevity Hill and has some significance for the protection of relics and other aspects.

\section{Acknowledgement}

Scientific research projects of Beijing Municipal Education Commission, 2017 (Item Number: KM201710009013)

\section{References}

[1] Pes G M, Tolu F, Dore M P, et al. Male longevity in Sardinia, a review of historical sources supporting a causal link with dietary factors.[J]. European Journal of Clinical Nutrition, 2015, 
69(4):411-418.

[2] Weisman A, Rovinski R, Lovblom L E, et al. Neuropathy Prevalence Compared to other Complications: Preliminary Analysis of the Canadian Study of Longevity in Diabetes Cohort[J]. Canadian Journal of Diabetes, 2015, 39(6):543-543.

[3] Zhu G, Zhou L, Wang Y, et al. Biogeographical distribution of denitrifying anaerobic methane oxidizing bacteria in Chinese wetland ecosystems[J]. Environmental Microbiology Reports, 2015, 7(1):128-138.

[4] Demerath E W, Guan W, Grove M L, et al. Epigenome-wide association study (EWAS) of BMI, BMI change and waist circumference in African American adults identifies multiple replicated loci[J]. Human Molecular Genetics, 2015, 24(15):4464-4479.

[5] Salisbury M J, Jicha B R, De Silva S L, et al. 40Ar/39Ar chronostratigraphy of Altiplano-Puna volcanic complex ignimbrites reveals the development of a major magmatic province[J]. Geological Society of America Bulletin, 2015, 123(5-6):821-840.

[6] Cesari M, Prince M, Thiyagarajan J A, et al. Frailty: An Emerging Public Health Priority[J]. Journal of the American Medical Directors Association, 2016, 17(3):188-192.

[7] Lee S H, Hong H R, Han T K, et al. Aerobic training increases the expression of adiponectin receptor genes in the peripheral blood mononuclear cells of young men[J]. Biology of Sport, 2015, 32(3):181-6.

[8] Caillouët K A, Keating J, Eisele T P. Characterization of aquatic mosquito habitat, natural enemies, and immature mosquitoes in the Artibonite Valley, Haiti[J]. Journal of Vector Ecology, 2015, 33(1):191-197.

[9] Tetzlaff D, Buttle J, Carey S K, et al. A preliminary assessment of water partitioning and ecohydrological coupling in northern headwaters using stable isotopes and conceptual runoff models[J]. Hydrological Processes, 2015, 29(25):5153-5173.

[10] Rita S, Morse N L. A Review of Dietary Selenium Intake and Selenium Status in Europe and the Middle East[J]. Nutrients, 2015, 7(3):1494-1537.

[11] Niu X, Yang J, Dilek Y, et al. Petrological and Os isotopic constraints on the origin of the Dongbo peridotite massif, Yarlung Zangbo Suture Zone, Western Tibet[J]. Journal of Asian Earth Sciences, 2015, 110:72-84.

[12] Lemaître J, Müller D W H, Clauss M. A test of the metabolic theory of ecology with two longevity data sets reveals no common cause of scaling in biological times[J]. Mammal Review, 2015, 44(3-4):204-214.

[13] Qualls W A, Müller G C, Traore S F, et al. Indoor use of attractive toxic sugar bait (ATSB) to effectively control malaria vectors in Mali, West Africa[J]. Malaria Journal, 2015, 14(1):1-8.

[14] Rijnsdorp A D, Bastardie F, Bolam S G, et al. Towards a framework for the quantitative assessment of trawling impact on the seabed and benthic ecosystem[J]. Ices Journal of Marine Science, 2016, 73(1):27-38. 